\title{
Vliv polohy nádrže v povodí při adaptivním rízení zásobní funkce
}

\section{PAVEL MENŠíK, MARTIN SOBEK}

\author{
Klíčová slova: adaptivita - inteligentní rízení - optimalizační model - předpovědní model - vodní nádrž - zásobní funkce
}

\section{SOUHRN}

V průběhu několika posledních let je možno pozorovat častější výskyt hydrologických extrémů. Dochází k častějšímu výskytu povodní a k prohlubování období sucha. Reálně je možné, že v prípadě po sobě opakujícího se výskytu několika déletrvajících období sucha může dojít k ohrožení zásobní funkce některých vodních zdrojů. Současný stav řízení zásobní funkce je dostačující, ale vzhledem ke klimatickému vývoji může být v blízké době nepostačující. Běžně používaný způsob řízení by mohl být rozšíren o inteligentní způsob řízení vycházející z principu adaptivity. Úspěšnost inteligentního řízení zásobní funkce byla již dříve prokázána. Předložený článek ověřuje vliv polohy nádrže v povodí při inteligentním (adaptivním) řizení zásobní funkce nádrže. Adaptivní rízení používá hydrologických předpovědí přítoků vody do nádrže v kombinaci s optimalizačním modelem. V článku uvedené výsledky poukazují na skutečnost, že je možno za určitých okolností úspěšně použít adaptivní rízení u nádrží situovaných v horní a i v dolní části povodí.

\section{ÚVOD}

V průběhu několika posledních let je možno pozorovat častější výskyt hydrologických extrémů. Dochází k častějšímu výskytu povodní a k prohlubování období sucha. Odborné práce z oblasti klimatologie na výskyt těchto extrémních událostí dlouhodobě upozorňují. Za zmínku stojí napríklad roky 2011 a 2012, které z hydrologického hlediska byly hodnoceny jako extrémně suché [1], a rovněž tak i minulý rok 2015 [2]. V blízké budoucnosti je možno očekávat, že se tyto události budou vyskytovat častěji a jejich negativní účinek bude mít progresivní trend.

Klimatické podmínky již přinutily širokou odbornou veřejnost k zamyšlení, zda je Česká republika dostatečně připravena na vznik možných problémů způsobených nedostatkem zásob vody. Z podnětů odborné veřejnosti došlo k vytvoření pracovní skupiny SUCHO. Skupina vznikla na přelomu let 2013/2014 a formulovala výčet opatření proti negativním dopadům potenciálního sucha vedoucí k předejití krizové situace vyvolané jeho výskytem a následným nedostatkem vody. Po spojení s již existující pracovní skupinou VODA došlo ke vzniku Mezirezortní komise VODA-SUCHO a po vzájemné spolupráci byl zpracován dokument [3]. Vytvořený dokument obsahuje obecný úvod do problematiky sucha včetně předkládací zprávy, zdůvodňující jeho potřebnost, a dále výčet približně padesáti konkrétních opatření proti negativním dopadům sucha. Koncepce popsaná v dokumentu byla 29. 7. 2015 usnesením vlády České republiky schválena.

Reálně je možné, že v případě po sobě se opakujícího výskytu několika déletrvajících období sucha může dojít k ohrožení zásobní funkce některých vodních zdrojů. Za předpokladu, že se tato hrozba stane skutečností a zásoba vody ve vodních nádržích nebude pro jejich provoz dostačující, bude možné řešení spočívat ve změně v provozování vodních děl. Tyto změny budou převážně predstavovat úpravu způsobu manipulace s řizeným odtokem. V krajním případě, pokud budou vyčerpány všechny možnosti ostatních adaptačních opatření k zajištění vodohospodářských služeb a kdy dopady klimatické změny nebudou rešitelné jinými prostředky pro jejich neproveditelnost nebo pro jejich neúměrné náklady, bude možno stávající nádrže rozširirit o nádrže nové. S touto myšlenkou byl v roce 2011 aktualizován generel území chráněných pro akumulaci povrchových vod [4]. Možností zmírnění dopadů změny klimatu využitím území chráněných pro akumulaci povrchových vod se rovněž věnuje práce, viz [5].

Od 70. let 20. století téměř nedošlo v oblasti strategického řízení (horizont řízení v časovém kroku měsíc) zásobní a hydroenergetické funkce u vodních nádrží k žádné významné změně. Postupně budeme zcela jistě svědky zesílení společenské poptávky nejen ve smyslu zdokonalování operativního řízení, ale rovněž ve smyslu změn základních strategických parametrů nádrží často s cílem významného posílení jejich zásobní funkce [6].

Současný stav rízení zásobní funkce je dostačující, ale vzhledem ke klimatickému vývoji může být v blízké době nepostačující. Klasické řízení zásobní funkce vodních nádrží vychází prevážně z pravidel řízení [7], resp. z dispečerských grafů [8]. Vytváření uvedených pravidel bylo prímo ovlivněno výkonností tehdejší výpočetní techniky, což mělo za následek jejich značné zjednodušení. Pravidla jsou vytvořena na základě historických průtokových řad. Použití historických průtokových řad pravidlům neumožňuje adaptivně reagovat na aktuální hydrologické podmínky. Z tohoto důvodu můžou současná pravidla rízení narážet na omezení plynoucí z měnících se hydrologických podmínek, které v historických průtokových řadách nemůžou být zahrnuty. Dnešní výkonnost výpočetní techniky umožňuje používané způsoby řizení rozširíit o nové tzv. inteligentní způsoby řízení. Inteligentní rízení umožní vhodnou manipulaci na vodních dílech. Vhodná manipulace dokáže predejít poruchám systému $\checkmark$ podobě nedodávky vody a také dokáže efektivně hospodařit s vodou pro hydroenergetické účely. V konečném důsledku úprava manipulace na vodních dílech může přinést podnikům povodí a ostatním společnostem výrazné ekonomické výhody v podobě hospodárné distribuce vody do systému a minimalizace možného vzniku ekonomických ztrát.

Běžně používaný způsob řízení by mohl být rozšíren o inteligentní způsob řizení. Inteligentní způsob řízení vychází z principu adaptivity. Adaptivní prístup umožňuje reagovat na průběžně se měnící hydrologické podmínky. Obvykle je k tomuto řízení potřebná znalost hydrologických predpovědí př́tokư vody do nádrží v kombinaci s optimalizačním modelem. $V$ praxi je možno principem adaptivity částečně eliminovat nepresnost předpovědi. Adaptivním řizením nádrží a vodohospodářských soustav se zabýval na přelomu 80. a 90. let profesor Nacházel a docent Patera [9-12]. 
Inteligentní způsob řízení by v budoucnu mohl být použit jako podpůrný nástroj pro vodohospodářský dispečink, kterému zejména při řízení složitějších systémů s více nádržemi a s uvažováním více vodohospodářských účelů poskytne vhodnou podporu při procesu rozhodování. Uvažovaný algoritmus ř́zení bude představovat jedno z možných opatření pro zmírnění negativních dopadů sucha a nedostatku vody. Takové rízení zcela zapadá do koncepce popsané v dokumentu [3] a je součástí organizačního a provozního opatření.

Úspěšnost inteligentního řízení zásobní funkce a hydroenergetické funkce nádrže a soustavy nádrží byla již dřive prokázána, bylo dosaženo zajímavých výsledků a tyto výsledky je možné vidět napríklad v [13-15]. Předložený článek si klade za cíl ověřit vliv polohy nádrže v povodí při inteligentním (adaptivním) řizení zásobní funkce nádrže. Je možno předpokládat, že výsledky z adaptivního řizení budou pro nádrže situované v různých částech povodí jiné. Za tímto účelem je rízení provedeno zvlášt pro nádrž, která je umístěna v horní části vodního toku, a následně pro nádrž, která je umístěna v dolní části vodního toku.

\section{POUŽITÉ METODY}

\section{Předpovědní model}

Pro vytvoření předpovědi průměrných měsíčních průtoků byl použit zonální pravděpodobnostní předpovědní model (ZPPM). Princip modelu je popsán $\checkmark$ následujících odstavcích. Z několikaleté historické průtokové raady průměrných měsíčních průtoků jsou vyčleněny jednotlivé roky $y=1,2 \ldots, Y$, kde $Y$ značí celkový počet let. Ze všech roků jsou následně vyčleněny i jednotlivé měsíce $m=1,2 \ldots, 12 \mathrm{~s}$ průměrnými měsíčními průtoky $Q_{m}$ pro každý rok množiny y. Tímto způsobem je vytvořena množina, která je tvořena průměrnými měsíčními prítoky vody do nádrže za celé sledované období $Y$ pro jednotlivé měsíce $m$. $V$ každém měsíci je potom nalezena minimální hodnota $\min Q_{m}$ a maximální hodnota $\max _{m}$ historického prítoku vody. Interval mezi hodnotami $<\min Q_{m}, \max _{m}>$ je rozdělen na predem zvolený počet zón. Počet zón $Z$ je $v$ každém měsíci stejný, velikost intervalu $<\min Q_{m^{\prime}}^{z} \max _{m}^{z}>$ se však může lišit. Velikost jednotlivé zóny je stanovena tak, aby splňovala požadavek, že každá zóna musí obsahovat približně stejný počet prvků $q_{m, y}$. Jednotlivé prvky $q_{m, y}$ každé množiny tvoří v príslušné zóně podmnožinu $Q_{m}^{z}$.

Podle počáteční průměrné hodnoty př́toku vody $Q_{m}^{c} \vee$ měsíci $m$, ve kterém je rozhodováno o řízení, je vybrána zóna $z$, pro kterou platí $Q_{m}^{c} \in$ $<\min Q_{m}^{z}, \max Q_{m}^{z}>$. Zónou z prochází vybraný soubor historických řad $s=1,2 \ldots$, $S$, kde $S$ je celkový počet řad procházející zónou. Pro každou řadu v souboru $S$ platí, že $q_{m s} \in Q_{m}^{z}$. Další členy historických řad s souboru $S$, které jsou reprezentovány prưměrnými měsíčními přítoky $a_{m+t s} \vee$ měsících $m+t$, kde $t$ je pořadí měsíce predpovědi, jsou pak použity pro určení intervalu zóny predpovědi $z p$. Pro $t$ platí $t=1,2 \ldots, T P$, kde TP je počet předpovídaných kroků (měsíců) a $q_{m+t s} \in Q_{m+t}^{z p}$. Pro pořadí měsíců $m+t>12$ platí $m+t-12$. Pro každý měsíc predpovědi $m+t$ je stanovena pouze jedna zóna předpovědi zp [10].

Hodnota průměrného měsíčního prítoku vody do nádrže $Q_{m+t}^{p} \vee$ měsíci i $m+t$ je rovna hodnotě vyskytující se $v$ intervalu zóny predpovědi zp $s$ největší pravděpodobností. Průměrné měsíční průtoky jsou potom předpovězeny podle následujícího principu. Pro všechny prvky $q_{m+t, s}$ z množiny $Q_{m+t}^{z p}$ je vytvořena hustota rozdělení pravděpodobnosti. Tvar spojité funkce je pro zjednodušení trojúhelníkový. Spodní hrana je tvořena intervalem $\left\langle\min Q_{m+t^{\prime}}^{z p} \max Q_{m+1}^{z p}>\right.$ a vrchol trojúhelníku leží na predpokládané poloze modu Mod veličiny $q_{m+t, s}$. Kurčení polohy modu je použit předpoklad, že platí:

$$
\int_{m i n Q_{m+t}^{z p}}^{\max } p\left(q_{m+t, s}^{z p}\right) d q_{m+t, s}=1
$$

Postup nalezení polohy modu na intervalu $<\min Q_{m+t^{\prime}}^{z p} \max Q_{m+t}^{z p}>$ je vyobrazen graficky na obr. 1 .

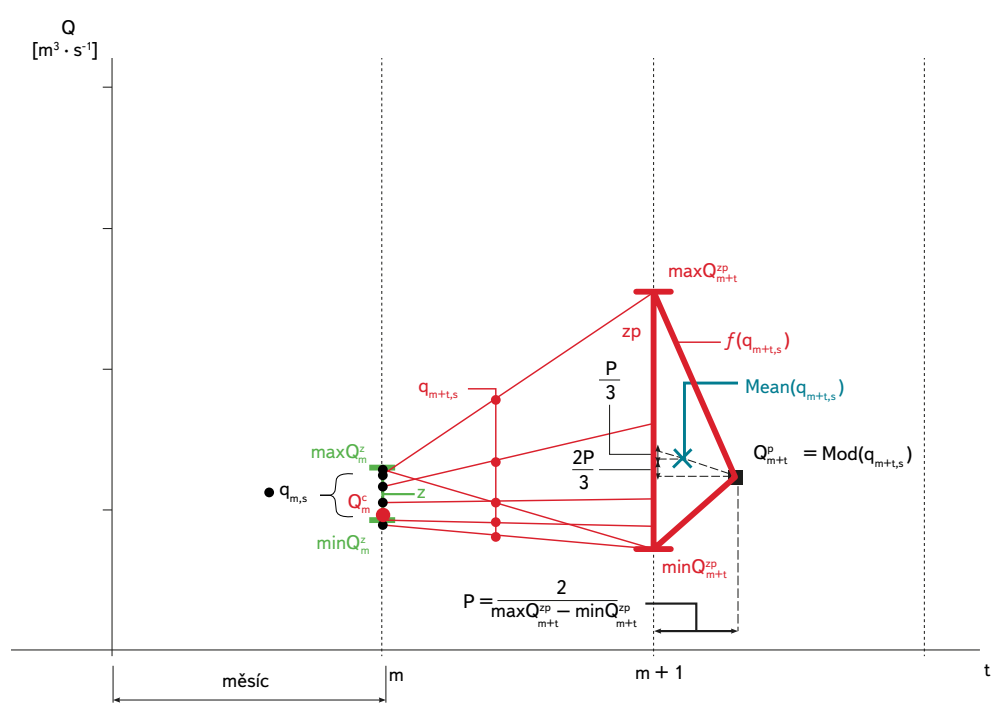

Obr. 1. Postup nalezení modu

Fig. 1. Procedure to find modus

Potom pro předpovězenou hodnotu prítoku vody do nádrže $v$ měsíci $m+t$ platí:

$$
Q_{m+t}^{p}=\operatorname{Mod}\left(a_{m+t, s}\right)
$$

Algoritmus vytváření předpovědí $Q_{m+t}^{p}$ pro více kroků (měsíců) je zobrazen na obr. 2 .

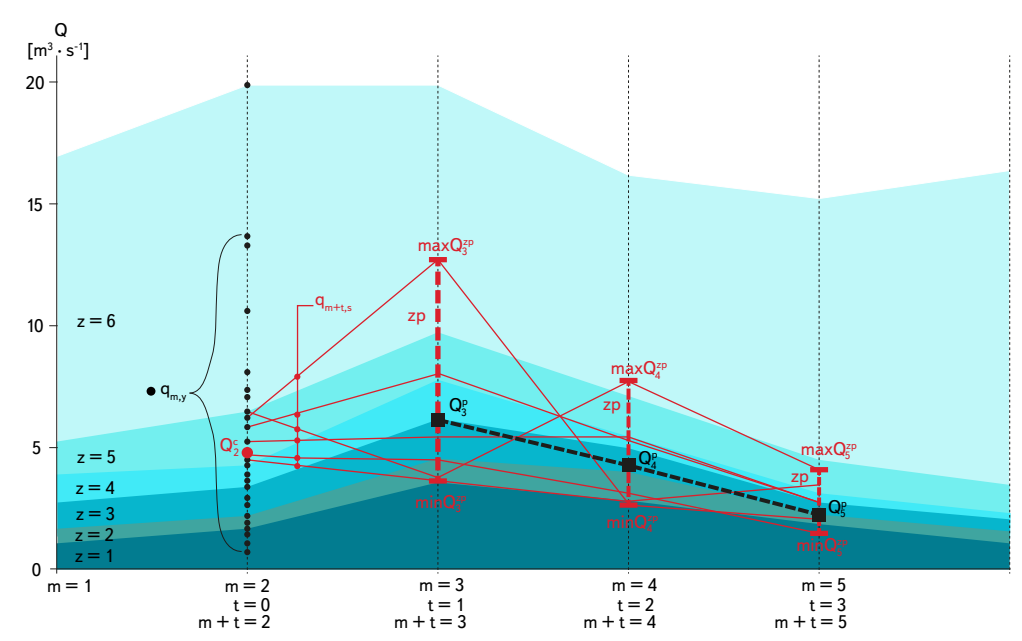

Obr. 2. Algoritmus vytvárení předpovědi

Fig. 2. Algorithm of making prediction 


\section{Algoritmus adaptivního řízení zásobní funkce}

Adaptivní řízení zásobní funkce nádrže je založeno na klasickém simulačním modelu (globální model). U simulačního modelu jsou pravidla řizení nahrazena opakovanou optimalizací (lokální model). Krok simulačního modelu je $T=1,2, \ldots, M$, kde $M$ je celkový počet kroků (měsíců). Algoritmus řízení je možno popsat ve třech krocích, které se postupně opakují.

$\checkmark$ prvním kroku je vytvořena předpověd" průměrných měsíčních přítoků vody do nádrže. K vytvoření predpovědi je použit ZPPM a délka předpovědi odpovídá zvolenému počtu predpovídaných měsíců.

Ve druhém kroku je sestaven optimalizační model nádrže. Průměrné měsíční odtoky z nádrže $O^{\top}$ na řizeném období jsou hledány optimalizací v každém časovém kroku lokálního modelu $\tau=1,2, \ldots \ldots, N$, kde $N$ je celkový počet kroků. K nalezení $O^{\top}$ je použita metoda diferenciální evoluce. Počet předpovídaných měsíců TP je roven počtu časových kroků N. Okrajovými podmínkami jsou předpovězené př́toky do nádrže. Počáteční podmínka řešení je objem vody $\checkmark$ nádrži na konci časového kroku $\tau=0$. Ve skutečnosti by se jednalo o naměřenou hodnotu objemu vody v nádrži. Jako kritérium optimalizace byl zvolen součet čtverců odchylek mezi řídicím odtokem $W^{\top}$ a skutečným řízeným odtokem $\mathrm{O}^{\tau}$ vody z nádrže, který je snaha minimalizovat. Kriteriální funkce (3) je ve tvaru, který zajištujuje rovnoměrné rozložení nedodávky vody mezi jednotlivé měsíce. Použití druhé mocniny ve funkci (3) je dáno předpokladem, že větší množství nedodané vody je hưře príijatelné než menší množství nedodané vody.

$$
\left[\pi=\sum_{\tau=1}^{N=T P}\left(W^{\tau}-O^{\tau}\right)^{2}\right] \rightarrow M I N
$$

Ve třetím kroku se na základě skutečného prítoku a nalezeného řizeného odtoku, který odpovídá prvnímu kroku lokálního modelu $\tau=1$, provede $v$ časovém kroku T simulace chování nádrže pomocí simulačního modelu. Počáteční podmínkou pro řešení další optimalizace je výsledná velikost objemu vody $\checkmark$ nádrži na konci časového kroku. Následně je optimalizace posunuta o jeden časový krok.

Kroky 1 až 3 se následně opakují pro každý krok globálního modelu T. Opakováním jednotlivých kroků se zároveň model adaptuje na nové podmínky. Celý proces adaptace je ukončen při dosažení časového kroku $T=M$.

K adaptivnímu řizení zásobní funkce nádrže byl použit program SOMVS (Simulační a optimalizační model vodohospodářské soustavy) [16]. Ve zkrácené formě byl software publikován např́klad $v$ impaktovaném časopise [17] a $\vee$ České republice [18]. SOMVS je licencovaný software Vysokého učení technického v Brně. Obecně je možno software použít pro strategické plánování (rozvoj, řizení) v oblasti zásobní funkce vodních nádrží. Software umožňuje najít optimální řešení problémů spojených se zásobováním obyvatelstva, průmyslu, energetiky a zemědělství vodou.

\section{Aplikace}

Pro aplikaci byly vybrány dva měrné profily, profil Vlaské a profil Kroměřǐž. Oba měrné profily leží na řece Moravě. Profil Vlaské se nachází v horní části povodí reky Moravy a profil Kroměříž je v dolní části povodí řeky Moravy. Profily byly vybrány s cílem provést adaptivní rízení zásobní funkce $v$ profilech s rozdílnou vodností - viz $Q_{a}$ v tabulce 1.

Na začátku bylo provedeno vodohospodářské řešení zásobní funkce nádrže. Byly stanoveny nutné velikosti zásobních objemů $V_{z}$ pro dvě fiktivní nádrže. První nádrž je situovaná v profilu Vlaské a druhá v profilu Kroměříž. Zásobní objemy byly stanoveny na základě známé hodnoty nalepšeného odtoku $O_{p}$ a za předpokladu dodržení stoprocentní zabezpečenosti odtoku vody z nádrže. Hodnota nalepšeného odtoku byla zvolena jako 0,3 (součinitel nalepšení a) násobek dlouhodobého průměrného průtoku $Q_{a}$. Výsledné hodnoty zásobních objemů fiktivních nádrží jsou spolu s ostatními hodnotami uvedeny v tabulce 1.

Následně bylo provedeno adaptivní rízení zásobní funkce fiktivních nádrží v období let 2000 až 2006. Období let 1950 až 2000 bylo použito pro kalibraci, tzn. pro vytvoření ZPPM. Adaptivní rízení bylo provedeno pro 7 různých hodnot řídicího (nalepšeného) odtoku - konkrétně se jednalo o násobky součinitele nalepšení a $\left(0,4 ; 0,5 ; 0,6 ; 0,7 ; 0,75 ; 0,8\right.$ a 0,9) a odpovídající hodnoty $Q_{a}$. Pro každou hodnotu rídicího odtoku proběhlo celkem 24 výpočtů, dvanáct pro řízení s predpovězenými průtoky (adaptivní řízení s předpovězenými průtoky - Ǎ̌ - P) a dvanáct pro řízení s reálnými průtoky (adaptivní rízení s reálnými průtoky $A \check{R}-\mathrm{R})$. Jednotlivé výpočty se od sebe lišily počtem časových kroků lokálního modelu. Výpočty s reálnými průtoky sloužily pro porovnání úspěšnosti ř́zení, jelikož je považujeme za ideální stav - v praxi nedosažitelný. Dále bylo provedeno řízení pro každou hodnotu řídicího odtoku pomocí prosté simulace (simulační model - SM). U simulačního modelu probíhá řešení odlišným způsobem, než je tomu u optimalizačního modelu. Omezující podmínky jsou rešeny postupně po jednotlivých časových krocích a v každém kroku je snahou, aby odtok vody z nádrže byl roven hodnotě řídicího (nalepšeného) odtoku. Simulační model považujeme za nejjednodušši způsob řízení a byl použit pro srovnání jednotlivých výsledků z řízení.

Úspěšnost uvažovaných zpưsobư rízení byla vyhodnocena pomocí kritéria K:

$$
K=\sum_{T=1}^{M} K^{T}
$$

Pokud byl řízený odtok $O^{T}$ větší než r rídicí odtok $W^{T}$, tak kritérium v časovém kroku $T$ bylo rovno nule $\left(K^{\top}=0\right)$. Pokud byl ř́zenýodtok $O^{T}$ menšínežřídicí odtok $W^{\top}$, bylo kritérium v časovém kroku $T$ vyhodnoceno jako čtverec rozdílu mezi řídicím a ř́zeným odtokem vody z nádrže $\left(K^{\top}=\left(W^{\top}-O^{\top}\right)^{2}\right)$.

Tabulka 1. Hodnoty zásobních prostorů jednotlivých nádrži

\begin{tabular}{|c|c|c|c|c|c|c|}
\hline Profil & Plocha povodí nad profilem & Ř́dicí plocha nádrže' & $\mathbf{Q}_{\mathrm{a}}$ & $a$ & $\mathbf{O}_{\mathbf{P}}$ & $\mathbf{v}_{\mathrm{z}}$ \\
\hline & $\mathrm{km}^{2}$ & $\%$ & $\mathrm{~m}^{3} \cdot \mathrm{s}^{-1}$ & - & $\mathrm{m}^{3} \cdot \mathrm{s}^{-1}$ & $m^{3}$ \\
\hline Vlaské & 96,55 & 0,4 & 1,88 & 0,3 & 0,564 & 2180270 \\
\hline Kroměříž & 7030,31 & 65 & 51,2 & 0,3 & 15,360 & 119269800 \\
\hline
\end{tabular}

Table 1. Values of storage capacity of each reservoir

'Procento řídicí plochy nádrže k celkové ploše povodí. 


\section{SHRNUTÍ VÝSLEDKU゚}

Z důvodu velkého množství rešených variant jsou v príspěvku prezentovány jen ty varianty, které z pohledu přehledného shrnutí mají stěžejní význam. Při řízení zásobní funkce fiktivní nádrže v dolním profilu Kroměřǐž je dosaženo vypovídajících výsledkư při řízení na rrídicí odtok odpovídající součiniteli nalepšení $a=0$,7. Při řízení s délkou předpovědi na jeden nebo na dva měsíce dopředu dosahuje řízení SM lepších hodnot kritéria než $A \check{R}$ - P nebo A dva časové kroky dopředu dosahuje adaptivní rízení lepších hodnot kritéria než při řízení SM. Průběhy kritérií u uvažovaných způsobů řizení pro rozdílné délky předpovědí (počet časových kroků lokálního modelu) jsou zobrazeny na obr. 3.

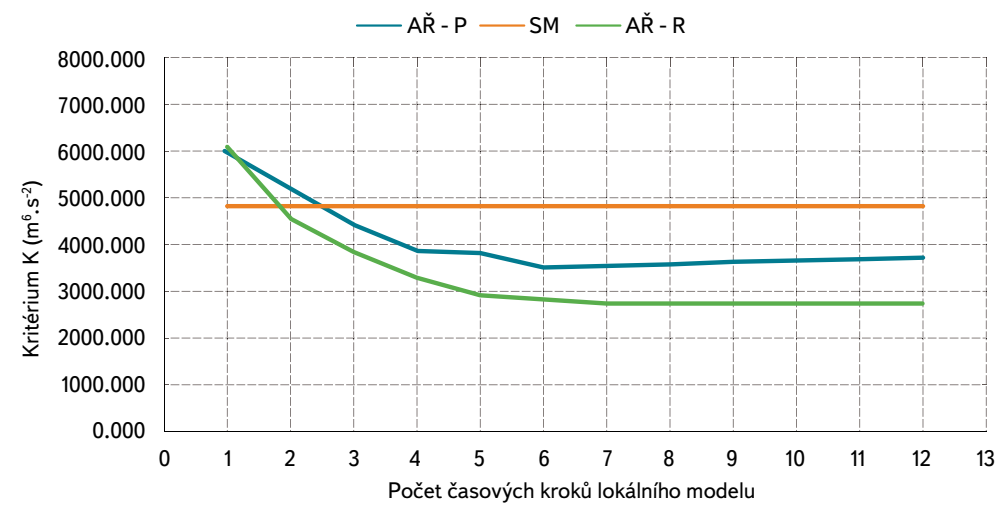

Obr. 3. Dolní profil Kroměříž - řízení na $a=0,7$

Fig. 3. Lower profile Kroměřiž - control of outflow on the $a=0.7$

Výše uvedené skutečnosti platí téměř pro všechny uvažované hodnoty řídicích odtoků. Výjimku tvoří pouze řizení na rídicí odtok odpovídající hodnotě součinitele nalepšení $a=0,75$, kde již i v prípadě délky předpovědi na jeden a dva

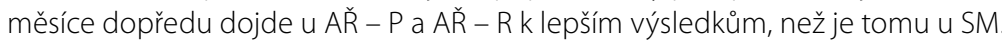

Na obr. 4 jsou znázorněny průběhy uvažovaných rízení na rídicí odtok odpovídající součiniteli nalepšení $a=0,7$ a pro profil Kroměříž. $Z$ důvodu přehlednosti a snadnější orientace $v$ grafu je vybrána pouze část časového období, ve které vznikla při řízení porucha. $V$ prípadě rízení SM je možno na obr. 4 vidět, že dosahuje nejhlubší poruchy při vzájemném srovnání s oběma variantami adaptivního řízení. Oba prípady adaptivních řizení používají délku předpovědi na šest měsíců dopředu. Délka předpovědi šest měsíců je zvolena na základě toho, že od této délky došlo k ustálení hodnoty kritéria $K$, kritérium se již s rostoucím počtem měsíců předpovědi (kroků lokálního modelu) významně neměnilo. Tato skutečnost je patrná z uvedeného obr. 3. V obou prípadech adaptivního řízení můžeme vidět, že dosahuji lepších výsledkư rízení, protože hloubka poruchy není tak velká jako u SM. Ǎ̌ - R zde dosahuje mírně lepších výsledků než AŘ - P.

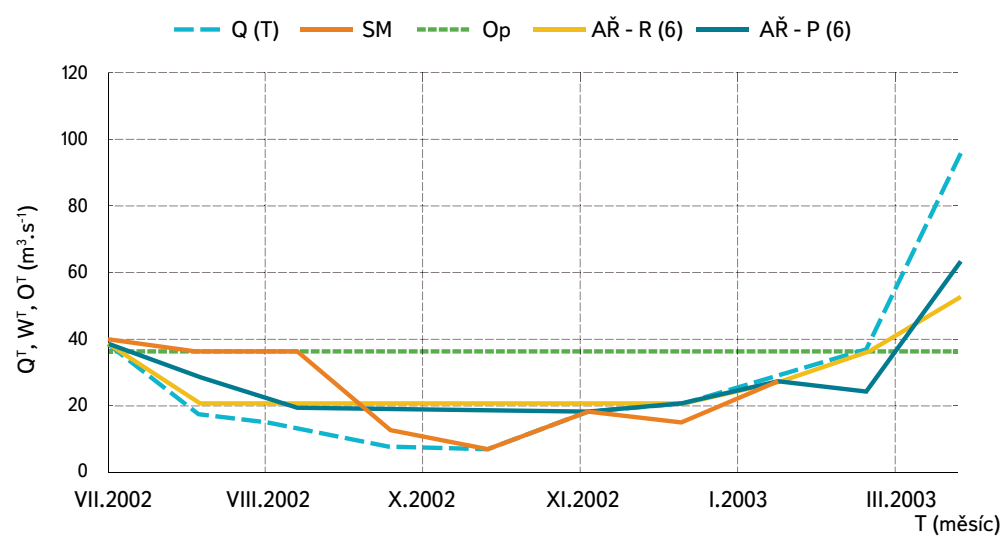

Při řizení zásobní funkce fiktivní nádrže v horním profilu Vlaské bylo dosaženo shodných výsledků jako u nádrže umístěné v dolním profilu Kroměříž. Výjimku tvoří pouze řízení na hodnotu součinitele nalepšení $a=0,4$ a $a=0,5$. Rozdíl spočívá v tom, že AŘ $-\mathrm{P}$ zde nedosahuje nikdy lepších výsledků než řízení SM. Důvod je především v minimálním výskytu poruchových měsíců, kdy není dostatek vody, a v nepresnosti předpovědního modelu, která se výrazněji projeví u nižších průtoků. Obdobným způsobem jako pro dolní profil Kroměříž jsou na obr. 5 a 6 zobrazeny výsledky pro horní profil Vlaské.

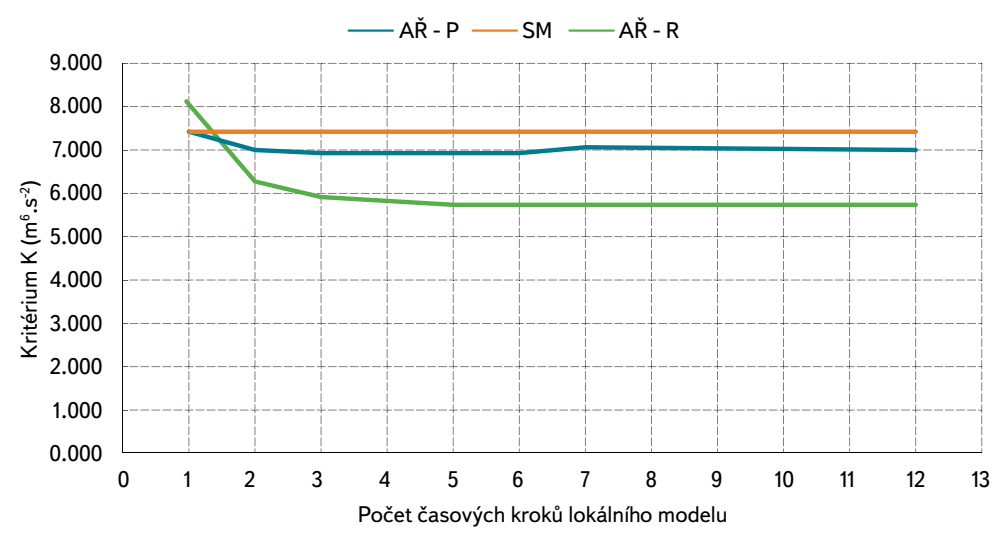

Obr. 5. Dolní profil Vlaské - řizení na $a=0,7$

Fig. 5. Higher profile Vlaské - control of outflow on the $a=0.7$

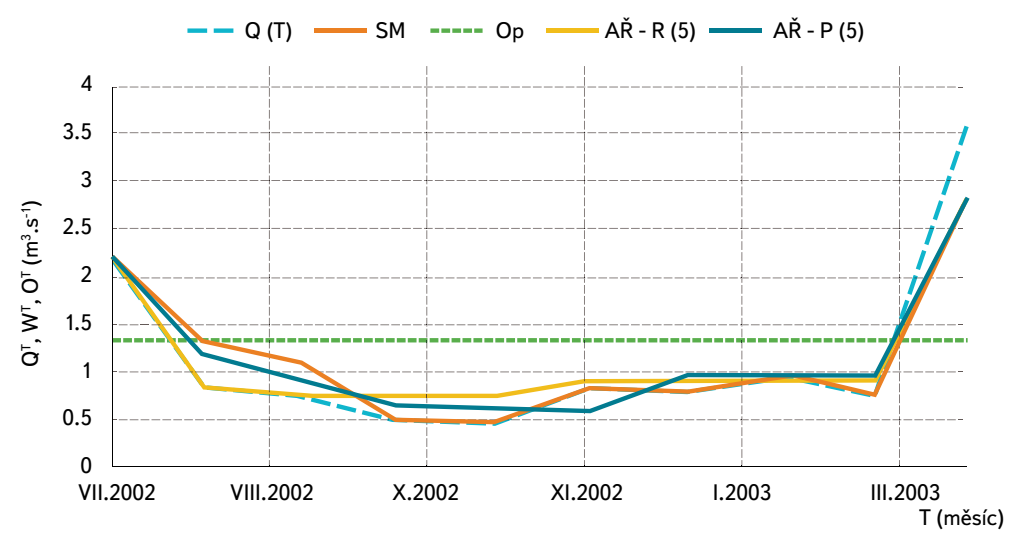

Obr. 6. Vybraný průběh řízení v profilu Vlaské

Fig. 6. Selected process of outflow control in profile Vlaské

\section{ZÁVĚR}

Článek si kladl za cíl ověrit vliv polohy nádrže v povodí při inteligentním (adaptivním) řízení zásobní funkce nádrže. Na základě dosažených výsledků je možno konstatovat, že z pohledu počtu předpovídaných měsíců (počtu časových kroků lokálního modelu) je dosaženo v obou profilech podobných výsledků. U předpovědi na jeden až dva měsíce jsou výsledky ve většině případů horší než u rrízení SM. S prírůstkem předpovídaných měsíců dojde k postupnému klesání kritéria. K ustálení kritéria dojde při řízení s předpovědí na 5 až 6 měsíců a následně se hodnota kritéria již nemění nebo se mění jen velmi málo.

Adaptivní řízení dosahovala nejlepších výsledků při vyšších hodnotách řizeného odtoku. Samož̌ejmě není možné nádrž, která je navržena na 0,3násobek dlouhodobého průměrného průtoku, rídit na řídicí odtok, který odpovídá 0,7násobku dlouhodobého průměrného průtoku. Ovšem v důsledku klimatických změň, při kterých Ize v průběhu hydrologického roku očekávat výskyt dlouhotrvajících období sucha střídajících se s obdobím prívalových deštư,

Obr. 4. Vybraný průběh řizení v profilu Kroměříž

Fig. 4. Selected process of outflow control in profile Kroměříž 
můžeme očekávat výrazný pokles dlouhodobého průměrného průtoku. Podle výsledků uvedených $v$ [19] hodnota dlouhodobého průměrného průtoku $\checkmark$ našich tocích může klesnout o 20 až $40 \%$.

Při řizení zásobní funkce nádrže se pokles dlouhodobého průměrného průtoku, při zachování stávajících požadavků na odběr vody (řídicí odtok), projeví tím, že dojde ke zvýšení hodnoty součinitele nalepšení $a$. Při uvažování pesimistického scénáře, uvažujícího s poklesem dlouhodobého prưměrného průtoku ○ 40 \%, by hodnota součinitele nalepšení, při zachování stávajícího požadavku na odběr vody, vzrostla z hodnoty $a=0,3$ na hodnotu $a=0,5$. $\vee$ prípadě, že by došlo i ke zvýšení požadavku na odběr vody, tak se může součinitel nalepšení přibližit hodnotě $a=0,6$. Při řízení na rídicí odtok odpovídající součiniteli nalepšení $a=0,6$ dosahuje adaptivní řizení zásobní funkce nádrže dobrých výsledků u obou profilů.

Dosažené výsledky poukazují na možnost budoucího praktického použití adaptivního rízení u nádrží situovaných v horní a i v dolní části povodí. Uvedený adaptivní způsob řízení zásobní funkce by mohl být prostředkem, kterým by bylo možno v budoucnu zefektivnit způsob hospodaření s vodou v nádržích. Obecně můžou inteligentní způsoby řízení představovat podpůrný nástroj pro vodohospodářský dispečink, kterému zejména při řízení složitějších systémů s více nádržemi a s uvažováním více účelů poskytnou vhodnou podporu při procesu rozhodování.

\section{Poděkování}

Článek je výsledkem specifického výzkumu FAST-S-16-3444 Návrh hybridní metody pro rízenízásobnífunkce nádrže.

\section{Literatura}

[1] ZAHRADNÍČEK, P., TRNKA, M., BRÁZDIL, R., MOŽNÝ aj. The extreme drought episode of August 2011-May 2012 in the Czech Republic. 2014. Int. J. Climatol. doi: 10.1002/joc.4211.

\section{[2] ČHMÚ. Drought in the Czech Republic in 2015: A preliminary summary. Prague, 2015.}

[3] Mezirezort VODA-SUCHO. Príprava realizace opatřeni pro zmirněni negativních dopadů sucha a nedostatku vody. Praha, 2015

[4] MZe a MŽP. Generel území chráněných pro akumulaci povrchových vod a základní zásady využití těchto území. Praha, 2011.

[5] KOŽíN, R., HANEL, M., KAŠPÁREK, L., aj. Možnosti zmírnění dopadů změny klimatu využitím území chráněných pro akumulaci povrchových vod. Vodohospodár̆ské technicko-ekonomické informace [online], 2015, roč. 57, č. 4-5, s. 11-17. ISSN 0322-8916. Dostupné z: http://www.vtei.cz/wp-content/ uploads/2015/08/vtei_2015_4_5_moznosti_zmirneni.pdf

[6] FOŠUMPAUR, P., KENDÍK, T. a BŘEZINA, K. Zodpovědný přistup při řešení možných změn strategického řízení nádrží. In: XXXIV. priehradné dni 2014. Slovenská republika, Horný Smokovec, 2014, s. 89-90. ISBN 978-80-971596-6-5.

[7] JAIN, S.K. Reservoirs-Multipurpose. Water Encyclopedia, 2005, p. 382-387.

[8] VOTRUBA, L. and BROZA, V. Water Management in Reservoirs. New York: Elsevier Science Ltd., 1989.

[9] NACHÁZEL, K. a PATERA, A. Možnosti využití principu adaptivity pro řízení nádrží v reálném čase. Vodohospodářský časopis, 1988, roč. 36, č. 3, s. 237-265.

[10] NACHÁZEL, K., PŘENOSILOVÁ, E. a PATERA, A. Možnosti využití principu adaptivity pro řizení kaskády nádrží v reálném čase. Vodohospodářský časopis, 1990, roč. 38, č. 4, s. 453-477.

[11] NACHÁZEL, K. Nelineární programování a optimalizace adaptivního řízení nádrží v reálném čase. Část 1: Optimalizace řízení v dané průtokové raadě. Vodohospodářský časopis, 1993, roč. 41, č. 1, s. 29-50.

[12] NACHÁZEL, K. a PATERA, A. Nelineární programování a optimalizace adaptivního řízení nádrží $\checkmark$ reálném čase. Část 2: Stochastický přístup k řízení. Vodohospodářský časopis, 1993, roč. 41, č. 4-5, s. 201-224.

[13] MENŠ́KK, P., STARÝ, M., and MARTON, D. Using Predictive Model of Mean Monthly Flows for Large Open Reservoirs Hydropower Control. Procedia Engineering, 2014, roč. 89, č. 12, s. 1486-1492. ISSN $1877-7058$.

[14] MENŠ́KK, P., STARÝ, M., and MARTON, D. Using Predictive Models of Mean Monthly Flows for Operative Outflows Control from Large Open Reservoirs. In Proceedings ITISE 2014. International conference on Time Series, Spain, Granada: Copicentro Granada S. L., 2014, p. 382-395. ISBN 978-84-15814-97-9.
[15] MENŠ́KK, P. MARTON, D., and STARÝ, M. Using Predictive Model for Strategic Control of Multi-reservoir System Storage Capacity. In: SGEM Conference Proceedings. International multidisciplinary geoconference SGEM. Hydrology and Water Resources. Bulgaria, 2015, s. 729-736. ISBN 978-619-7105-36-0. ISSN 1314-2704.

[16] MENŠÍK, P. a STARÝ, M. SOMVS - Simulačni a optimalizační model vodohospodářské soustavy. Dostupné z: http://uvhk.fce.vutbr.cz/somvs.php

[17] MENŠ́K , P., STARÝ, M., and MARTON, D. Water Management Software for Controlling the Water Supply Function of Many Reservoirs in a Watershed. Water Resources, 2015, vol. 42, no. 1, p. 133-145. ISSN 0097-8078.

[18] MENŠ́K, P., STARÝ, M. a MARTON, D. Automatizace řešení zásobní funkce vodohospodářské soustavy. Vodohospodárské technicko-ekonomické informace [online], 2015, roč. 57, č. 1, s. 2-5. ISSN 0322-8916. Dostupné z: http://www.vtei.cz/wp-content/uploads/2015/08/vtei_2015_1.pdf

[19] KAŠPÁREK, L. Odhad objemu nádrži potřebného pro kompenzaci poklesu odtoku vlivem klimatické změny. VúV Praha, 2005.

\section{Autoři}

Ing. Pavel Menšík, Ph.D.

$凶$ mensik.p@fce.vutbr.cz

\section{Ing. Martin Sobek}

凶martinsobek3@gmail.com

Ústav vodního hospodářství krajiny, Fakulta stavební, Vysoké učení technické v Brně

Příspěvek prošel lektorským řízením. 


\section{INFLUENCE OF POSITION RESERVOIR IN THE WATERSHED AT AN ADAPTIVE CONTROL OF THE STORAGE CAPACITY}

\section{MENSIK, P.; SOBEK, M.}

Institute of Landscape Water Management, Faculty of Civil Engineering, Brno University of Technology

Keywords: adaptivity - intelligent control - optimization model prediction model - open water reservoir - storage capacity

In recent years, it is possible to observe more frequent occurrence of hydrological extremes, there is a more frequent occurrence of floods and deepening drought. Realistically, it is possible that in case of repetitive occurrence of several longer periods of drought the storage function of some water resources may be endangered. The current state of control of active storage capacity is sufficient, but due to climatic developments may soon be insufficient. A commonly used method of control could be enhanced by the intelligent contro method based on the principle of adaptivity. The success of intelligent control of active storage capacity has been demonstrated beforehand. The paper validates the influence of the position of the reservoir in the basin in intelligent (adaptive) control of active storage capacity. Adaptive control uses hydrological prediction water inflows into the reservoir, combined with optimization model. The results of article point to the fact that in some circumstances it is possible to use successfully adaptive control of the active storage capacity of reservoirs, which are situated at the top part and also the bottom part of the river basin.

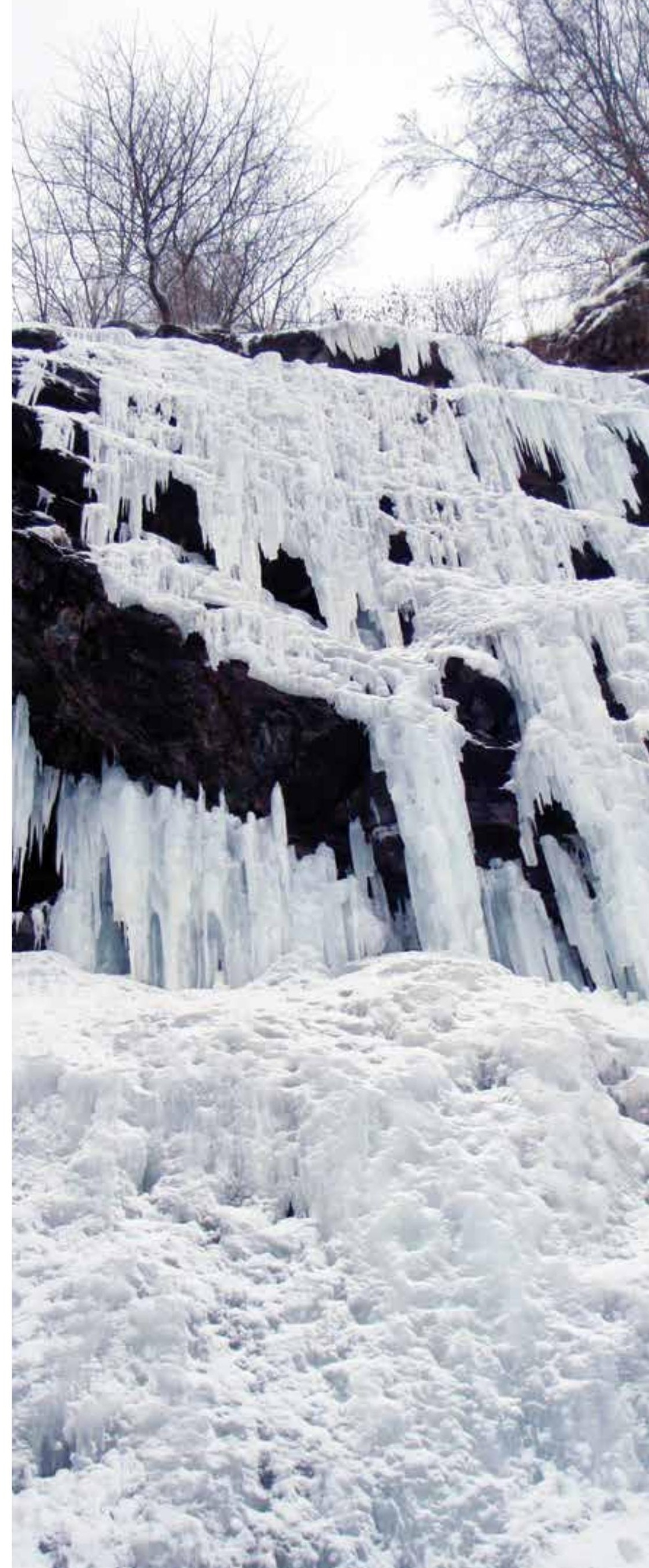

